Johnson, K., T. B. Neville, J. W. Smith, and M. W. Horner. 2016. Home range- and colony-scale habitat models for Pinyon Jays in piñon-juniper woodlands of New Mexico, USA. Avian Conservation and Ecology 11(2):6. http://dx.doi.org/10.5751/ACE-00890-110206

Copyright (C) 2016 by the author(s). Published here under license by the Resilience Alliance.

Research Paper

\title{
Home range- and colony-scale habitat models for Pinyon Jays in piñon- juniper woodlands of New Mexico, USA
}

\author{
Kristine Johnson ${ }^{1}$, Teri B. Neville ${ }^{1}$, Jacqueline W. Smith ${ }^{1}$ and Mark W. Horner ${ }^{1}$ \\ ${ }^{1}$ Biology Department, University of New Mexico
}

\begin{abstract}
Despite the Pinyon Jay's (Gymnorhinus cyanocephalus) importance as a piñon tree seed disperser and its long-term population declines, piñon-juniper habitat use by Pinyon Jays has been little studied. We created home range- and colony-scale habitat suitability models for Pinyon Jays in piñon-juniper woodlands at Kirtland Air Force Base and White Sands Missile Range, New Mexico, USA. Home range-scale models included mainly Juniper Woodland and Savanna, Piñon-Juniper, and Piñon Woodland vegetation types. Although home range-scale models at the two study sites contained similar vegetation types, we found differences between colonyscale models in habitat use and within-site diversity. Because of topographic and vegetation differences, colony-scale modeling incorporated fewer vegetation types and topographic classes for the White Sands Missile Range Study site than at Kirtland Air Force Base. Predictive colony-scale models overlapped validation colonies by $75.9 \%$ and $100 \%$ at the two study sites, indicating good model predictability. The large sizes of Pinyon Jay home ranges make year-round, home range-scale habitat management challenging. Habitat conservation focused at more limited spatial, i.e., colony, and temporal scales, revealed by multiscale modeling, could be more feasible and potentially more effective than management at the larger home range scale.
\end{abstract}

\section{Modèles d'habitat élaborés aux échelles du domaine vital et de la colonie chez le Geai des pinèdes dans les boisés de pins et de genévriers au Nouveau Mexique, États-Unis}

RÉSUMÉ. Malgré l'importance du Geai des pinèdes (Gymnorhinus cyanocephalus) en tant que vecteur de dispersion de graines du pin pignon et la baisse de longue date de ses effectifs, l'utilisation de l'habitat de pins-genévriers par ce geai a été peu étudiée. Nous avons élaboré des modèles de la qualité de l'habitat aux échelles du domaine vital et de la colonie chez le Geai des pinèdes dans les boisés composés de pins et de genévriers à la Kirtland Air Force Base et au White Sands Missile Range au Nouveau-Mexique, ÉtatsUnis. Les modèles à l'échelle du domaine vital incorporaient essentiellement les types de végétation allant des boisés et des savanes dominés par les genévriers, aux boisés mixtes de pins-genévriers et aux pinèdes. Même si les modèles à l'échelle du domaine vital comportaient des types de végétation semblables aux deux sites d'étude, nous avons trouvé des différences entre les modèles à l'échelle de la colonie pour ce qui est de l'utilisation de l'habitat et la diversité à l'intérieur d'un même site. En raison de différences sur le plan de la topographie et de la végétation, la modélisation à l'échelle de la colonie incorporait moins de types de végétation et de classes topographiques pour le site de White Sands comparativement au site de Kirtland. Les prédictions issues des modèles à l'échelle des colonies correspondaient à 75,9 et à $100 \%$ à la localisation des colonies de validation aux deux sites d'étude, ce qui indique une bonne capacité prédictive des modèles. Étant donné les grands domaines vitaux chez ce geai, l'aménagement de l'habitat à cette échelle et à longueur d'année représente un défi de taille. La modélisation multi-échelles révèle que les mesures de conservation de l'habitat fondées sur des échelles temporelle et spatiale plus limitées, c.-à-d. à l'échelle de la colonie dans le cas de cette dernière, seraient plus réalistes et sans doute plus efficaces que l'aménagement à l'échelle plus grande du domaine vital.

Key Words: colony; Gymnorhinus cyanocephalus; habitat; home range; model; piñon-juniper; Pinyon Jay; scale

\section{INTRODUCTION}

Pinyon Jays (Gymnorhinus cyanocephalus) and piñon pines have a mutualism whereby the trees provide mast crops of nutritional seeds that affect the jays' population viability, and the jays cache the seeds in the ground, serving as the tree's main long-distance seed disperser (Marzluff and Balda 1992, Lanner 1996). Pinyon Jays also depend on piñon and juniper trees for nest sites (Johnson et al. 2014, 2015). Despite recent climate impacts to piñon-juniper vegetation and a long-term decline of Pinyon Jay populations (Sauer et al. 2014), there is "no known detailed quantification of habitat anywhere within its range" (Balda 2002:4). To manage and conserve Pinyon Jays and their piñon-juniper habitats in the face of a changing climate and other impacts, it is necessary to understand the habitat requirements of the piñon pine's most important long-distance seed disperser.

Piñon-juniper (Pinus edulis, P. monophylla, Juniperus spp.) woodlands cover approximately 40,000,000 ha of the western USA (Romme et al. 2009). Recent, climate-related impacts to piñon-juniper woodlands include dramatic, large-scale mortality of piñon pines (Allen-Reid et al. 2008, Breshears et al. 2005), significant reductions in canopy cover (Clifford et al. 2011), and declines in piñon cone production (Redmond et al. 2012). Under likely climate change scenarios, the range of piñon-juniper habitat is predicted to move northward (Thompson et al. 1998, Cole et 
al. 2007). Recent models predict massive, widespread piñon and juniper mortality across the southwestern USA by 2100 , which will have "profound impacts on carbon storage, climate forcing, and ecosystem services" (McDowell et al. 2016:299).

Although fire has been found to play a role in structuring some piñon-juniper woodlands in the southwestern USA, birds, insect pests, and drought are also critical in the establishment and demise of these woodlands (Romme et al. 2009). Pinyon Jays serve as short- and long-distance seed dispersers for piñon pines. Adapted for carrying and caching millions of seeds in a few weeks, a Pinyon Jay flock is capable of replanting a woodland decimated by fire, drought, or insect pests (Ligon 1978). The Clark's Nutcracker (Nucifraga columbiana), the only other long-distance seed disperser of piñon seeds, is a less important seed disperser than the Pinyon Jay because the nutcracker forages in smaller flocks, forages in a wide variety of pine forests and woodlands, and often occurs at higher elevations than piñon pine woodlands (Tomback 1998).

Pinyon Jays are highly social, nesting colonially at traditional colony sites, and sometimes breeding cooperatively, with helpers at the nest (Marzluff and Balda 1992, Balda 2002). They are yearround residents of the southwestern USA, their distribution completely overlapping that of piñon trees (Marzluff and Balda 1992). When not nesting, they commonly travel over large landscapes in foraging flocks of up to several hundred individuals (Balda 2002). However, the sizes of nonbreeding flocks in recent anecdotal reports are much smaller than those reported historically (Bailey 1928, Linsdale 1936), as Pinyon Jay populations have been declining for over 40 years (Sauer et al. 2014).

Piñon trees produce mast crops of piñon seeds, which provide critical nutrition that enhances Pinyon Jay reproductive success and survival (Ligon 1978, Marzluff and Balda 1992). The Pinyon Jay's extraordinary physiological and behavioral dependence on piñon seeds is exemplified by reversal of gonadal regression in winter and breeding behavior in 11 months of the year, stimulated by abundant piñon seeds (Ligon 1978). Pinyon Jays also nest in larger than average piñon and juniper trees and in areas of high canopy cover (Johnson et al. 2014, 2015).

Because of Pinyon Jay dependence on piñon pines for food and nest sites (Ligon 1978, Lanner 1996), climate impacts to piñon mast production, tree health, canopy cover, and distribution will likely negatively impact the jay's populations. Decline of the piñon's primary long-distance seed disperser will limit the potential of the trees to re-establish in areas of high mortality, colonize higher elevations, or shift distributions northward in response to climate impacts, thus limiting climate resilience of piñon habitats. Pinyon Jay populations in turn will be further impacted by habitat loss.

Pinyon Jays must make habitat choices on at least three scales (Fig. 1):

1. The home range of a Pinyon Jay flock typically includes thousands of hectares and several land cover or ecosystem types, both characteristics of the landscape scale (Ferrari and Ferrarini 2008). Hence, because of their large sizes and diverse land cover types, Pinyon Jay home range habitat models are at the landscape-scale (hereafter "home range scale" for simplicity).
2. Pinyon Jay nesting colony sites within the larger home range must contain suitable habitat for 14 - 32 nesting pairs (Marzluff and Balda 1992), covering 5-41 hectares (based on nine colonies, Johnson et al. 2014, 2015). The size of a nesting colony site is characteristic of the ecosystem scale (1 - 100 hectares, Ferrari and Ferrarini 2008), hereafter "colony scale."

3. Each Pinyon Jay pair must then choose a suitable tree and nest site within the nesting colony, on a scale of approximately one hectare. Because home range- and colony-scale models are both commonly based on geospatial data (Ferrari and Ferrarini 2008), we address these two scales here (Fig. 1). Habitat use at the nest scale, beyond the scope of this paper, is addressed separately (K. Johnson, G. Sadoti, and J. Smith, unpublished manuscript).

Fig. 1. Scales of Pinyon Jay (Gymnorhinus cyanocephalus) habitat use. Home ranges (landscape scale) cover thousands of hectares. Nesting colonies (ecosystem scale) within home ranges cover tens of hectares; multiple nesting colonies can occur within one flock home range. Within nesting colonies, individual nest sites (not addressed in this paper) are smaller than one hectare; multiple nests occur within a nesting colony. Land cover data (background) over each study site were used to create both home range- and colony-scale models.

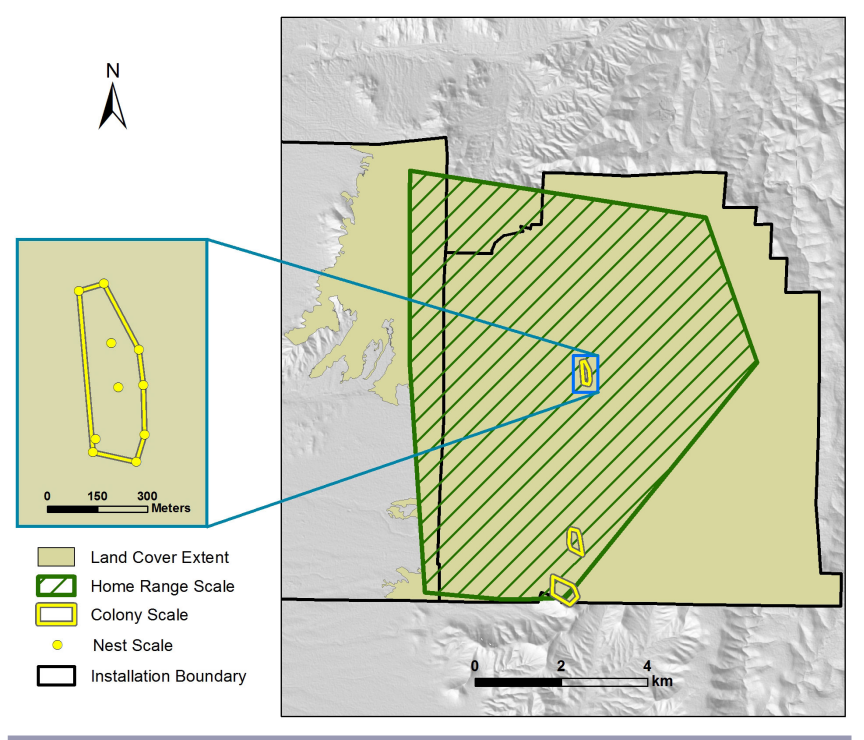

The goal of this study was to create predictive geospatial (geographic information system, GIS) models of Pinyon Jay habitat use at the home range and nesting colony scales in piñonjuniper woodlands, to inform habitat conservation and Pinyon Jay management. Specific objectives were the following: (1) to establish differential habitat use at the scale of the home range (based on radio telemetry and ground occurrence data); (2) to create predictive models at the scale of the nesting colony (delineated based on nest locations within colony sites) to identify a limited subset of the available piñon-juniper habitat, with characteristic vegetation type and topography suitable for nesting; and (3) to understand scale implications in applying the geospatial models to Pinyon Jay conservation and management. 


\section{METHODS}

\section{Study areas}

The two study areas were chosen because each was home to a Pinyon Jay flock of up to 50 individuals that maintained a home range and nested therein at traditional nesting colonies. Nesting colonies differed in topography and vegetation type and thus presented the opportunity to model a range of nesting colony habitats.

Kirtland Air Force Base (KAFB; 20,359 ha) is located in central New Mexico, USA (Fig. 2). Piñon-juniper habitats at KAFB occur primarily on the western slopes and bajadas of the Manzanita Mountains, a north-south chain that connects the higher Sandia Mountains to the north (elevation $3255 \mathrm{~m}$ ) and Manzano Mountains (elevation $2802 \mathrm{~m}$ ) to the south. KAFB has approximately 7733 ha of juniper and piñon-juniper habitats ranging in elevation from 1742 to $2439 \mathrm{~m}$. The study area extends from lower-elevation juniper woodlands through mixed piñonjuniper woodland; piñon-dominated woodland; and, at highest elevations, ponderosa pine (P. ponderosa) woodland. Precipitation comes primarily during the summer months, in the form of heavy, short-duration thunderstorms. Annual precipitation varies from $20.3 \mathrm{~cm}$ in arid valleys and mesas to $76.2 \mathrm{~cm}$ in the Sandia Mountains (Kirtland Air Force Base 2007). At the Albuquerque Airport weather station, the average monthly temperature ranges from $-4.7^{\circ} \mathrm{C}$ in January to $33.2^{\circ} \mathrm{C}$ in July (Western Regional Climate Center 2010).

Fig. 2. Map showing study areas in New Mexico, USA: Kirtland Air Force Base (Manzanita Mountains) and White Sands Missile Range (Oscura Mountains).

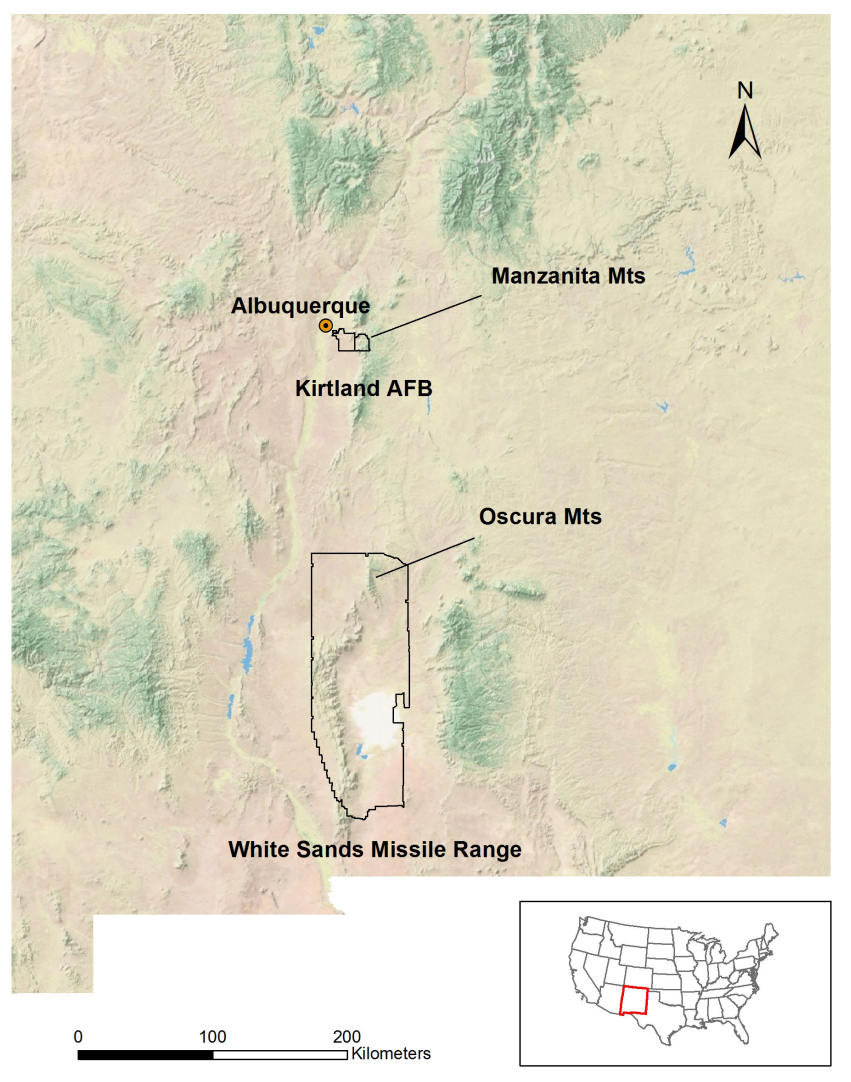

White Sands Missile Range (WSMR; $\approx 885,910$ ha excluding buffer extension areas) is located in south-central New Mexico, USA (Fig. 2). The Oscura Mountains (maximum elevation 2431 $\mathrm{m}$ at North Oscura Peak) are east-tilted, fault-block mountains with west-facing escarpments. The range of piñon-juniper vegetation types at WSMR is similar to that at KAFB, except that ponderosa pine woodland is not present at WSMR. The climate in the Oscura Mountains is semiarid, with average annual precipitation $31 \mathrm{~cm}$, coming mainly during short-duration, intense thunderstorms in July and August. Average monthly temperatures range from $-3.1^{\circ} \mathrm{C}$ in December to $27.1^{\circ} \mathrm{C}$ in June at the WSMR study site (T. Blaine, WSMR climate station 2009, unpublished data).

\section{Home range-scale habitat use}

\section{Kirtland Air Force Base home range-scale habitat use}

During the spring and summer months from March 2009-May 2011, we surveyed for Pinyon Jays in piñon-juniper habitats (Juniper Woodland and Savanna, Piñon-Juniper Woodland, and Piñon Woodland) at KAFB. In 2009, we also surveyed in all other months to establish the nonbreeding range of the Pinyon Jays. We visited areas frequented by the birds and collected Global Positioning System (GPS) coordinates where we found jays (accuracy $\pm 3-4 \mathrm{~m}$ ). When detections were in restricted areas or we could not reach locations on hillsides, we recorded approximate locations on a map within the GPS unit.

In July 2009, we erected an automatic koi feeder and livestock watering tub where jays had been detected. The feeder was supplied with $P$. edulis seeds and water was kept in the tub. In August 2009, we trapped Pinyon Jays near the feeder in a $107 \mathrm{x}$ $61 \times 20 \mathrm{~cm}$ welded wire walk-in trap designed after a standard pigeon trap and baited with $P$. edulis seeds. In March and December 2010 and February 2011, we also trapped jays near a feeder maintained by a KAFB security guard. Each bird was banded with a USGS numbered aluminum band and a unique combination of three plastic color bands. We attached 2.0-g, tailmounted, whip antenna radio transmitters (Holohil Systems, Ltd.) to 14 birds (three captured in 2009, eight in 2010, and three in 2011). We tied each transmitter to the base of the two central rectrices with sturdy thread, then used cyanoacrylate glue to fasten the body of the transmitter to the top of the same two rectrices. All birds were released unharmed after processing. Pinyon Jays were captured and banded under USGS Federal Marking and Salvage Permit \#22158, New Mexico Department of Game and Fish Scientific Permit \#1795, and University of New Mexico animal protocol \#10-100451-MCC.

After transmitters had been attached to the birds, we used a TRX $1000 S$ receiver from Wildlife Materials International, Inc. to track radio-tagged birds, on average 1.4 times each week (range $=0$ 5) from mid-August through November and twice in December 2009 (mean transmitter life $=105$ days, range $=86-119$ ). When we detected a transmitter, we recorded our location and took the compass bearing of the strongest signal. We then attempted to take a second GPS point and directional bearing from a different location, to triangulate on the bird's location. Using ArcGIS (Esri 2009), we mapped the vector indicating the direction of the radio signal. Where the vectors crossed, we added a point to signify the approximate location of the bird. Each point location was associated with date, time elapsed between observations, weather, 
transmitter frequency, and general location. We combined all GPS coordinates of Pinyon Jay point locations derived from visual detection, audio detection, and radio telemetry into a geospatial layer. Because of flock movements, only telemetry locations resulting from bearings taken 25 or fewer minutes apart provided useful point locations for transmitters $(n=11)$. Also because of bird movements, most points resulted from two intersecting bearings. The two points based on three bearings, both from WSMR, resulted in polygons of $408 \mathrm{~m}^{2}$ and $629 \mathrm{~m}^{2}$. We divided GPS point locations into breeding (1 March through 31 July) and nonbreeding (1 August to 28 February).

\section{White Sands Missile Range home range-scale habitat use}

We visited the study site at WSMR on average 1.1 times per week (range 0 - 3) from 24 March through 29 October 2009. On 10 April 2009, we set up a solar-powered, battery-operated automatic feeder (Sweeney Enterprises, Boerne, TX) within the area of Colony WA. The feeder delivered about two cups of $P$. edulis seed twice daily. On five days from June-August 2009, we trapped Pinyon Jays in a modified Australian crow trap set near the feeder and baited with $P$. edulis seed. We processed captured birds as at KAFB.

We attached radio transmitters to four of the birds captured at Colony WA. We tracked birds with a TRX-1000 receiver, either following the birds until we could see them or triangulating on their location as at KAFB. We attempted to locate the radio-tagged birds weekly from the time we banded them until the last transmitter batteries failed or birds left the area. We mapped locations as at KAFB. We collected bird location data for the modeling study in 2009, but we had additional Pinyon Jay location data from ground surveys in 2005, 2008, 2009, and 2011 at WSMR, which were incorporated into models.

\section{Both study sites}

Telemetry points indicated the location of an individual, but because Pinyon Jays are highly social, individuals were typically with other jays; hence, individual locations were indicative of a flock's home range. To delineate home ranges, using Arc GIS 10.2 (Esri 2013) we created minimum bounding geometry polygons around the set of detection points, excluding repetitive points at nests and feeders.

We adjusted the use of habitat type (land cover class) according to availability within the year-round Pinyon Jay home ranges by computing a concentration of use index (Neatherlin and Marzluff 2004), the probability of use for a land cover type in the home range divided by the occurrence of that land cover in the home range. Land cover classes composing $<5 \%$ of the breeding, nonbreeding, or year-round home range tended to have inflated concentration of use values relative to the most-used habitat types (one detection in a very small area results in an inflated use value). We therefore report concentration of use only for those land cover types composing $>5 \%$ of the home range polygons.

\section{Home range-scale habitat modeling}

We created home range-scale models using Pinyon Jay observation data from KAFB 2009-2011 and WSMR 2005, 2008, 2009, and 2011. We first created a land cover map over the KAFB study area. A vegetation classification, map, and associated plot data (E. Muldavin, G. Harper, P. Neville, Y. Chauvin, and P. Mehlhop, unpublished data) were available for the WSMR study area.

\section{KAFB home range-scale habitat modeling}

The Mid-Region Council of Governments provided six-inchresolution, natural color, digital ortho-imagery of Bernalillo County (MRGCOC 2008) flown in March and April 2008 covering all habitats at KAFB. Using this imagery, we delineated 72 polygons that contained Juniper Woodland and Savanna, Piñon-Juniper Woodland, and Piñon Pine Woodland overlapping and surrounding areas where Pinyon Jays had been observed across the study area. We visited 69 of the 72 polygons, where we took photos and made preliminary assignments to vegetation type. Mean polygon area was 8.6 ha (range: $0.12-67$ ha; total polygon area $=597 \mathrm{ha}, 6 \%$ of final mapped area). We used these data to define map units for a classification of vegetation in the study area.

At scales of 1:3000-6000, we applied aerial photo-interpretive techniques of visual landscape elements including color, texture, and size, with overlays of elevation contours and field data descriptions, to create the land cover map. Finally, we delineated 325 polygons for potential field checking in areas of known Pinyon Jay activity in areas with access unrestricted by KAFB. We visited 89 of these (mean area: 3.8 ha, range: $0.03-21$ ha) that were reasonably accessible and concentrated in the habitat types used by the jays. We collected the following data: date, GPS coordinates, aspect of the described slope, percent cover class of the dominant species, canopy cover, and relative cover of piñon and juniper. These data were used to refine the habitat classification.

Dick-Peddie (1993) defined woodlands as having trees with nonoverlapping canopies and distinguished juniper savanna as scattered stands with densities less than 130 trees/acre. Using these definitions as a guideline, we classified those areas where piñon accounts for $25-50 \%$ of the cover as Piñon-Juniper Woodland. We classified Piñon Woodland as areas where piñon makes up > $50 \%$ of the cover (based on our field data, extrapolated to similar areas on the imagery). Juniper-dominated classes contain $<25 \%$ piñon. We considered the vegetation types overlapping Pinyon Jay occurrence and home range polygons to be Pinyon Jay habitat but also mapped all nonwoodland land cover types within the study area.

\section{WSMR home range-scale habitat modeling}

To model home range-scale habitat use by Pinyon Jays at WSMR, we referenced the existing vegetation map and associated plot data, in combination with 1-m, natural-color, aerial photography acquired in July 2009 (NAIP 2009); existing data on tree species and size; and Pinyon Jay occurrence datasets (Johnson and Smith 2006, 2008, Johnson et al. 2014). We assigned all land cover types within the study area. We used our detection points and home range polygons to assign the vegetation types containing Pinyon Jay occurrences to Pinyon Jay habitat.

\section{Colony-scale predictive modeling}

Colony-scale models were created in 2013 but employed nest location data from 2010-2012 and the land cover map created in 2010 at KAFB and nest location data from 2007, 2009, and 2010-2012 at WSMR. We located nesting colonies at both study sites by surveying for Pinyon Jays during April and May from 2007 - 2012. We noted locations of jays showing breeding behaviors such as display flights, rattle calls, stick manipulation, silent sitting, or nest construction (Berger and Ligon 1977, Balda 
2002). From a distance, we watched birds constructing nests and returned to the area after nesting was complete to collect GPS coordinates of known nests and search the colony area for additional nests, some of which remained from previous years (distinguishable from those of other species that nest at the study site).

Each nesting colony is designated by a unique letter combination indicating study site $(\mathrm{K}=\mathrm{KAFB}, \mathrm{W}=\mathrm{WSMR})$ and the order it was found (A, B, C). In 2010, we found one nesting colony at KAFB, KA. A colony found in 2009 (13 nests), and occupied for only one year, was not used for colony-scale modeling because we were concerned that its location in atypical habitat was influenced by proximity of the feeder. At WSMR, Colony WA was occupied from $2007-2009$ and WB was occupied from 2010 - 2011. In 2012, we found two new nesting colonies at KAFB (Colonies KB and $\mathrm{KC}$ ) and one new colony at WSMR (Colony WC). Geospatial data from colony sites $\mathrm{KA}, \mathrm{KB}, \mathrm{WA}$, and $\mathrm{WB}$ were used as the basis for the colony-scale predictive models; nests from Colonies $\mathrm{KC}$ and $\mathrm{WC}$ were reserved for model validation.

We used nest locations to define the extent of colonies at KAFB and WSMR, then collected geospatial data described in Appendix 1, Table A1.1, sampled at $100 \mathrm{~m}^{2}$ from within the nesting colony boundaries and across the study area. To define biophysical habitat features important at the nesting colony scale for both sites, we developed and applied topographic and satellite-derived data available at colony-and-above scales (Appendix 1). We used 15 topographic predictors derived from digital elevation models, seasonal solar radiation, and vegetation indices derived from Landsat 5 Thematic Mapper satellite data acquired in 2005. (Appendix 1 lists topographic predictors [Table A1.1] and justifies their inclusion).

\section{KAFB colony-scale predictive modeling}

We performed a clustering analysis within Colonies $\mathrm{KA}$ and $\mathrm{KB}$, using the ISODATA algorithm in ERDAS Imagine software (Hexagon Geospatial, ERDAS 2011), which creates an unsupervised classification based on pixel similarities. The unsupervised classification yielded 20 classes.

Some of the 15 geospatial layers were likely correlated with one another. To determine if a subset of the geospatial layers would be sufficient, we used the Jeffries-Matusita distance formula, (Swain and Davis 1978), which eliminated five layers while still maintaining high separability (mean $=1400.82,0-1414$ possible) between the 20 classes. Eliminating additional layers resulted in a significant drop in separability to 1200 or less. The five eliminated layers were: July NDVI (Normalized Difference Vegetation Index), January Moisture, October Moisture, Planiform Curvature (rate of elevation change perpendicular to slope), and Profile Curvature (rate of elevation change in direction of slope).

We then classified the study area, using a minimum-distance classifier. The supervised classification was based on statistics derived from the unsupervised classification of the nesting colonies. The result was a 20-class supervised classification based on the 10 geospatial measures. The 20 classes fell naturally into three groups with similar landscape position (low, medium, and high slopes) and spatial contiguity. To include the influence of both geospatial features and vegetation types, we merged the three geospatial classes with the three primary vegetation types, to make nine new classes that included vegetation and topographic information: high to moderate to low slopes in Piñon Pine Woodland, Piñon-Juniper Woodland, and Juniper Woodland and Savanna.

Next, we ran a neighborhood analysis for diversity over the entire study area, using a $32 \times 32$ matrix (of the $10 \times 10 \mathrm{~m}$ cells), approximately equal to the area of our smallest known nesting colony. This analysis identified polygons with class diversity and area similar to that of known colonies (diversity values from 7 10 , out of 10 ). We converted the raster file containing diversity values $\geq 7$ to vector format and calculated the percent cover value of Juniper Woodland and Savanna, Piñon-Juniper Woodland, Piñon Woodland, and no value for each polygon, for a total of 981 polygons. No-value polygons represent nontarget map classes such as shrubland. The percent cover values were input into the ArcGIS 10.2 (Esri 2013) Grouping Analysis tool to combine adjacent, categorically similar polygons. A spatial constraint allowed only contiguous polygon features of the same class that shared edges or vertices to be included in a group. The grouping analysis resulted in 15 polygons. We retained four additional, isolated but otherwise-qualified polygons eliminated by the Grouping Analysis tool.

We then created rules for retaining only polygons that conformed to the vegetation profiles of the two known colonies. These rules were the following: (1) retained polygons must contain $\geq 10 \%$ Piñon Woodland; (2) together the Piñon Woodland and Piñonjuniper Woodland must compose $\geq 45 \%$ of the polygon; (3) nontarget (nonpiñon-juniper) vegetation types must compose < $15 \%$ of the polygon. The resulting 11 polygons had geospatial measures and vegetation characteristics similar to the Colonies $\mathrm{KA}$ and $\mathrm{KB}$.

\section{WSMR colony-scale predictive modeling}

We used the same approach to colony-scale modeling at WSMR. Because WSMR differed in topography and vegetation from KAFB, some steps used for KAFB did not work well for WSMR and were eliminated, as noted below. For WSMR, we started with 16 geospatial layers (Appendix 1, Table A1.1) and assembled the geospatial data within the study area. We attempted an unsupervised classification of Colonies WA and WB using ISODATA clustering with the same number of classes as at KAFB, but the resulting classification was highly pixelated and did not cluster well. We repeated the clustering analysis, specifying fewer classes until it produced a five-class classification that was not highly pixelated. The resulting matrix from the unsupervised classification performed within the two colonies (WA and WB) was noninvertible (invertibility is a requirement for the JeffriesMatusita distance formula to reduce the number of geospatial measures). This left all 16 geospatial measures for the unsupervised classification. We then used the minimum-distance classifier to create a five-class, supervised classification of the study area outside the colonies, based on the statistics generated by the unsupervised classification of Colonies WA and WB.

A diversity focal analysis like that performed at KAFB was unsuccessful at WSMR. First, many WSMR nests were near the escarpment edge, which resulted in nesting colony-sized polygons that contained more nonhabitat than suitable habitat. Second, the WSMR colonies used for modeling were situated on a gentle, east-facing slope; hence, the geospatial measures (slope, aspect, elevation, etc.) showed very low variation relative to those at 
Fig. 3. Pinyon Jay (Gymnorhinus cyanocephalus) breeding season, nonbreeding season, and year-round observations and home ranges at Kirtland Air Force Base (KAFB) and White Sands Missile Range (WSMR). Home ranges created by minimum bounding geometry (minimum convex) polygons. Background shows land cover classes.

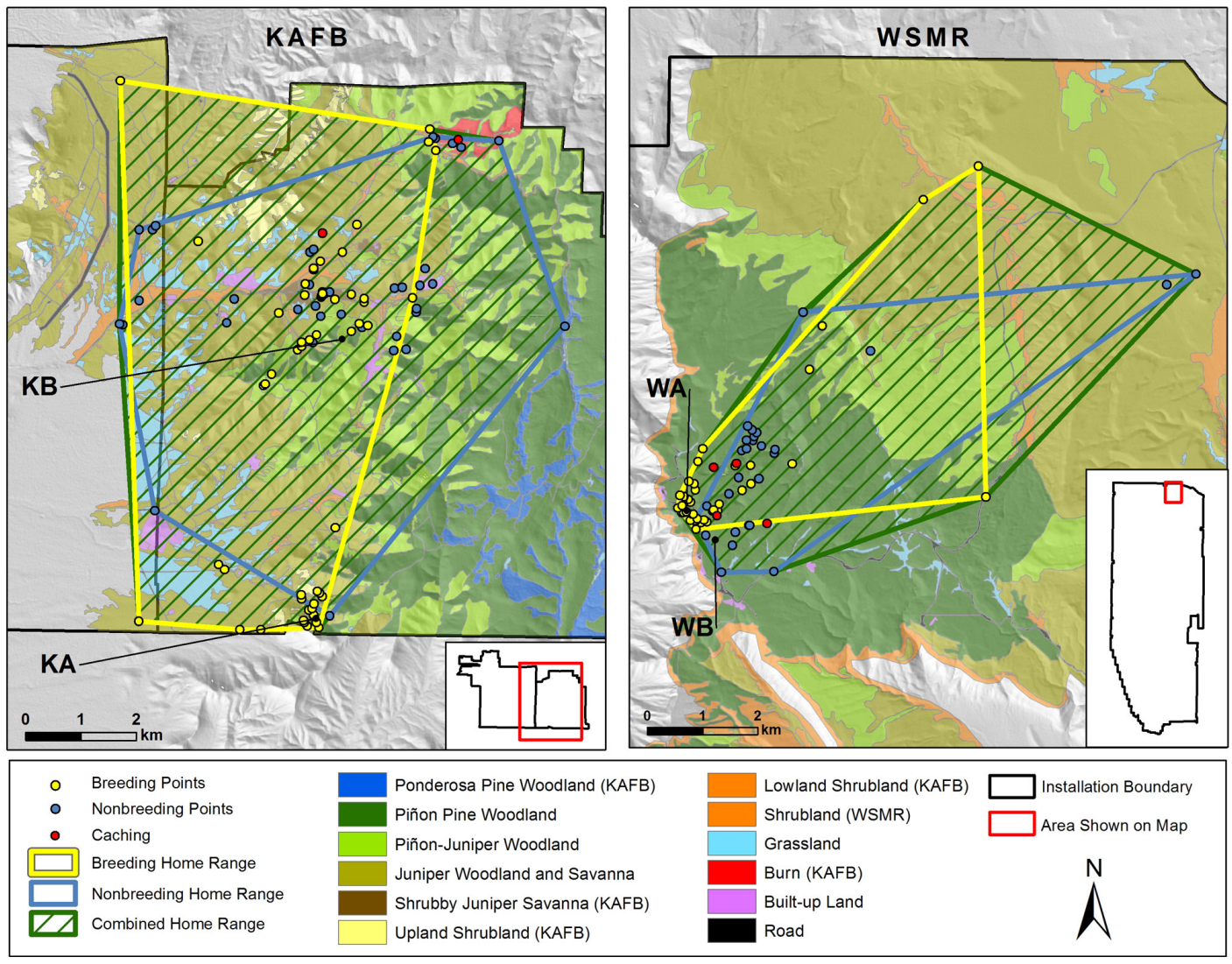

KAFB. Third, colonies occurred on only one vegetation type, Piñon Woodland, further reducing topography/vegetation diversity of the study area.

Of the five geospatial classes produced by the supervised classification, we retained the four having Pinyon Jay nests. We then merged the extent of the remaining geospatial classes with the land cover map of the study area and eliminated cells with vegetation types that did not contain Pinyon Jay nests, which were only found in Piñon Woodland. We eliminated small, isolated polygons and retained contiguous polygons that included all four nest-related classes. The resulting predictive colony-scale model for WSMR identifies areas having similar vegetation and geospatial characteristics to those of Colonies WA and WB.

\section{Validation of nesting colony models}

In April 2013, we field surveyed all except four small KAFB colony site polygons predicted by the model. We walked through each polygon, listening and watching for Pinyon Jays. We assumed we were able to hear jays vocalizing within $200 \mathrm{~m}$ and therefore covered each model polygon with walking transects approximately $400 \mathrm{~m}$ apart. For validation of the KAFB colonyscale model, we computed the percent overlap of the minimum bounding polygon of Colony KC (12 nests) with the KAFB colony model. For validation of the WSMR colony-scale model, we did the same for Colony WC (10 nests).

\section{RESULTS}

\section{Home range-scale habitat use}

Kirtland Air Force Base home range-scale habitat use

At KAFB from 2009 to 2011, we captured 66 Pinyon Jays and attached transmitters to 14 . From the transmitters, we obtained 23 useful intersecting bearings resulting in 11 point locations (from 3 transmitters, 2-6 locations each). Ground surveys yielded 126 additional point locations. Of the 137 bird locations, 103 (non-nests inside the mapped area) were used for assessing differential habitat use. We used 44 nest locations to delineate colonies (Colony $\mathrm{KA}=22, \mathrm{~KB}=10$ ) and validate the nesting colony model ( $\mathrm{KC}=12$ nests).

The breeding-season home range polygon at KAFB covered 4418.9 ha, and the nonbreeding season home range was 4599.4 ha. The year-round range covered 5978.0 ha.

Colony KA was situated in steep Piñon Woodland and PiñonJuniper Woodland. Colony KB was centered on slopes of PiñonJuniper Woodland extending north to an area of Juniper Woodland and Savanna (Fig. 3). Our banding and telemetry data indicate that individual jays moved between the north and south ends of the KAFB home range, and the two nesting colonies were occupied by members of the same nonbreeding season flock. 
Fig. 4. Concentration of use (CU) by Pinyon Jays (Gymnorhinus cyanocephalus) in breeding, nonbreeding, and combined season home ranges at Kirtland Air Force Base and White Sands Missile Range. $\mathrm{CU}=$ probability of use for a land cover type in the home range divided by the occurrence of that land cover in the home range. CUs for land cover types composing $>5 \%$ of home range polygons are presented.

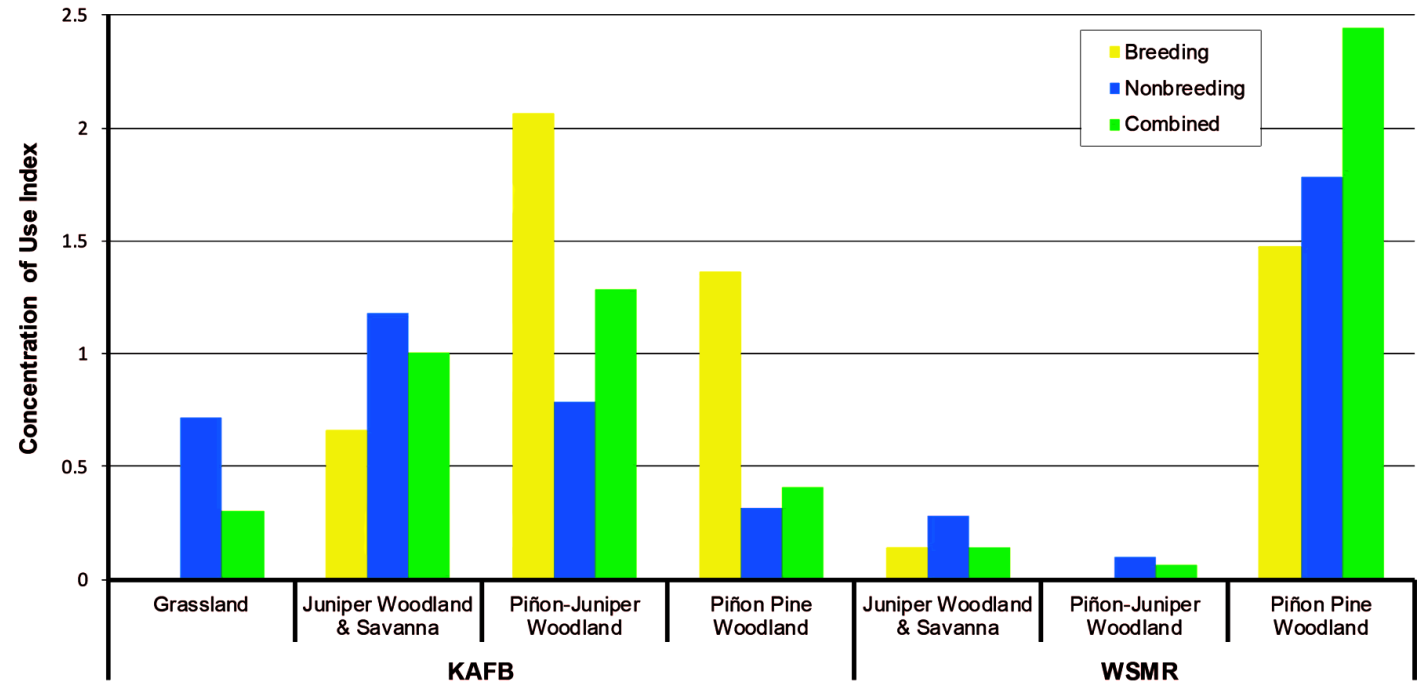

We observed jays caching seeds in two areas. In early spring 2009, they retrieved caches in open habitat at the top of a previously burned hill (Fig. 3, north caching area). The south caching area (Fig. 3), used in both breeding and nonbreeding seasons, is a mostly south-facing, 18-ha, sparsely vegetated, gentle hillslope dominated by grasses and shrubs with scattered juniper trees.

\section{White Sands Missile Range home range-scale habitat use}

In 2009, the focal year for the home range-scale study, we captured 21 Pinyon Jays and attached transmitters to four. We obtained 79 transmitter bearings that provided 17 point locations (from 4 transmitters, 2-6 locations each). Ground survey data from 2005 , 2008, 2009, and 2011 yielded 107 additional point locations. Of the 124 bird locations, 71 (non-nests inside the classified area) were used for assessing differential habitat use. We used 44 nest locations to delineate colonies (Colony WA $=13, \mathrm{WB}=21)$ and validate the colony-scale model ( $\mathrm{WC}=10$ nests).

The WSMR breeding season home range polygon covers 2041.7 ha (Fig. 3). The nonbreeding home range includes 2059.8 ha, and the combined breeding and nonbreeding range covers 3580.1 ha (Fig. 3). The WSMR flock left the nesting area (Colony WA and WB, Fig. 3) after the breeding season every year from 2005 to 2010. We collected several observations in September and October, but we do not know where they winter; hence, the breeding and nonbreeding home ranges combined are not yearround ranges for WSMR, as they are for KAFB.

At WSMR, we observed Pinyon Jays caching piñon seeds in August and September in only two years: 2006, when a moderately sized cone crop occurred, and 2011, when a small crop was produced. Birds cached in Piñon Woodland and Piñon-Juniper Woodland in both years but not in large, open areas as at KAFB (Fig. 3).

\section{Home range-scale habitat models}

\section{KAFB home range-scale habitat model}

The land cover types within the KAFB study area, covering 9424.6 ha, include Ponderosa Pine Woodland, Piñon Pine Woodland, Piñon-Juniper Woodland, Juniper Woodland and Savanna, Shrubby Juniper Savanna, Upland Shrubland, Lowland Shrubland, Grassland, Burn, Built-up Land, and Road (Fig. 3). A subset of the map units in the study area is primary habitat for Pinyon Jays at KAFB. This 7733.5-ha landscape ranges in elevation from approximately $1742 \mathrm{~m}$ to $2439 \mathrm{~m}$ and includes Piñon Pine Woodland, Piñon-Juniper Woodland, and Juniper Woodland and Savanna. We have observed Pinyon Jays in the Ponderosa Pine Woodland east of KAFB, and it is likely that KAFB jays occasionally ranged into that habitat. However, we do not include Ponderosa Pine in this model, because we have no location data indicating that Pinyon Jays from the KAFB flock ranged into the Ponderosa Pine Woodland.

The majority of year-round Pinyon Jay ground and telemetry detections at KAFB (2009 - 2010) were from Juniper Woodland and Savanna (48.5\%, $n=50)$, Piñon-Juniper Woodland $(23.3 \%$, $n=24)$, and Piñon Woodland $(5.8 \%, n=6)$. Midelevation PiñonJuniper Woodland (concentration of use $[\mathrm{CU}]=2.06$ ) and highelevation Pinyon Pine Woodland $(\mathrm{CU}=1.36)$ were more heavily used than Juniper Woodland and Savanna $(\mathrm{CU}=0.66)$ in the breeding season (Fig. 4). Lower-elevation Juniper Woodland and Savanna $(\mathrm{CU}=1.18)$ was more heavily used than the other two types in the nonbreeding season $(\mathrm{CU}=0.79$ and 0.32 , respectively), and Grassland was also used, with $\mathrm{CU}=0.72$ (Fig. 4). The CU in the year-round home range is similar for PiñonJuniper Woodland (1.29) and Juniper Woodland and Savanna (1.0), whereas the year-round CU for Piñon Pine Woodland and Grassland were 0.41 and 0.30 , respectively (Fig. 4). 


\section{WSMR home range-scale habitat model}

The land cover map for Pinyon Jays in the WSMR study area covers $22,465.9$ ha of potential habitat ranging in elevation from approximately 1800 to $2430 \mathrm{~m}$. The land cover types in this map are Piñon Pine Woodland, Piñon-Juniper Woodland, Juniper Woodland and Savanna, Shrubland, Grassland, Built-up Land, and Road. Piñon Pine Woodland, Piñon-Juniper Woodland, and Juniper Woodland and Savanna cover 19,598.6 ha (Fig. 3).

At WSMR, combined breeding and nonbreeding Pinyon Jay observations are from Piñon Pine Woodland $(87 \%, n=62)$, Juniper Woodland and Savanna $(5.6 \%, n=4)$, and Piñon-Juniper Woodland $(1.4 \%, n=1)$. Breeding season use was heavily concentrated in Pinyon Pine Woodland: $\mathrm{CU}=1.47$ vs. 0.14 in Juniper Woodland and Savanna (Fig. 4). Nonbreeding season CUs were: Pinyon Pine Woodland $=1.78$, Pinyon-Juniper Woodland $=0.1$, and Juniper Woodland and Savanna $=0.28$ (Fig. 4), indicating slightly increased use of lower-elevation PinyonJuniper Woodland and Juniper Woodland and Savanna in the nonbreeding season. CUs for both seasons combined were Pinyon Pine Woodland $=2.44$, Juniper Woodland and Savanna $=0.14$, and Pinyon-Juniper Woodland $=0.06$.

Numbers of detections were higher in the breeding season, because birds left the study area in the fall. Nonbreeding season CUs likely underestimate the use of Juniper Woodland and Savanna in the nonbreeding season at WSMR, because of the incompleteness of our spatial data for wintering Pinyon Jays at WSMR.

\section{Colony-scale predictive models}

\section{KAFB colony-scale predictive model}

The final KAFB colony-scale model covers 1446 ha. The model contains 11 predictive colony-scale polygons, each of a different class but similar in topography and vegetation to $\mathrm{KA}$ and $\mathrm{KB}$ Colonies (Fig. 5). On average, the 11 predicted habitat polygons contained $43.71 \%$ Piñon Woodland (Range $=19.14-68.07, S E$ $=4.30), 47.32 \%$ Piñon-Juniper Woodland (Range $=31.54-67.63$, $S E=3.09$ ), and $7.16 \%$ Juniper Woodland and Savanna (Range $=0-30.41, S E=3.29)$. The mean elevation for the 11 model polygons was $2122.09 \mathrm{~m}($ Range $=1901.91-2333.61, S E=20.48)$. The mean slope was $23.07^{\circ}$ (Range $=0.07-76.09, S E=0.92$ ). The cosine aspect ranged from -1.0 to $1.0, S E=0.07$ ). Eight of 11 mean aspect cosines were positive, indicating that most colony polygon slopes generally face north. The locations of these potential nesting colony sites are shown in Figure 5. Together, the 11 groups delineate potential nesting colony sites and cover $15.35 \%$ of the study area land cover map and $18.7 \%$ of the available Piñon Woodland, Piñon-Juniper, and Juniper Woodland and Savanna map units.

\section{WSMR colony-scale predictive model}

The predictive colony-scale model at WSMR covers 2309 ha, $10.3 \%$ of the entire WSMR land cover map and $41 \%$ of the Piñon Woodland map unit (Fig. 6). The WSMR colony-scale model includes areas with mean elevation of $2346.86 \mathrm{~m}$ (Range: $2086.06-2632.82, S D=102.15 \mathrm{~m})$. The mean slope is $11.61^{\circ}$ (Range $=0.01-51.11, S D=5.57)$. The mean cosine of aspect is -0.05 (Range $=-1.0-1.0, S D=0.56)$, indicating more southerly aspects.
The modeling process at WSMR unfolded quite differently from that at KAFB. Because the unsupervised classification resulted in a noninvertible matrix, evaluation of divergence among the classes prevented further reduction of the dimensionality of the data, and we were left with the original 16 layers for the classification. Because colonies on WSMR were much less diverse than KAFB colonies in terms of floristics and topography, attempts to apply focal analysis to aggregate classes based on diversity at the 10-ha scale were unsatisfactory.

Fig. 5. Kirtland Air Force Base Pinyon Jay (Gymnorhinus cyanocephalus) colony-scale predictive habitat model and nesting colonies. Colony model is shown in bright colors; other land cover is shown in muted colors. Geospatial and vegetation data from within the KA and KB Colonies were used to create the colonyscale model. Colony $\mathrm{KC}$ area was used for model validation. $100 \%$ of KC colony area fell within predictive model.

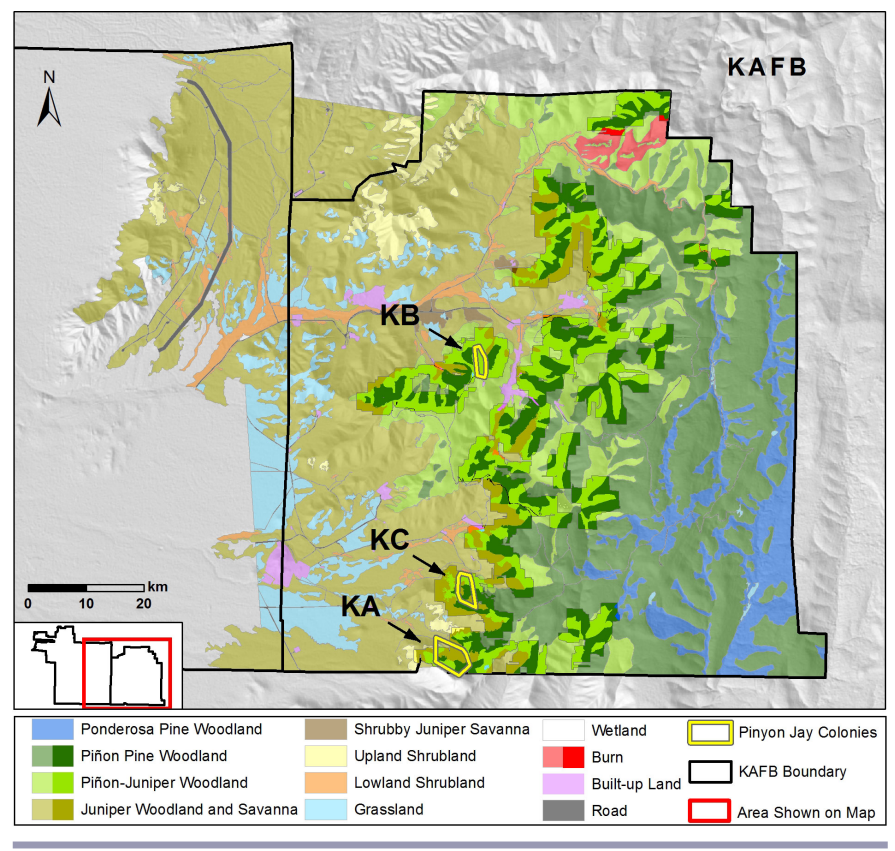

The resulting model includes large areas in which the four classes of interest were relatively equally distributed. Because we were not able to distinguish nesting colony sites from the surrounding Piñon Woodland based on different biophysical characteristics, we concluded that the entire area similar to the colony sites should be classified as two predicted nesting colony polygons, our study site and another more southerly site within the Oscura Mountains (Fig. $6)$.

\section{Validation of colony-scale models}

We found validation colonies during ground surveys in 2012. We found no previously unknown, active colonies during the surveys of the nesting colony model area. The validation colony at KAFB fell entirely within the colony-scale predictive model (Fig. 5). The validation colony at WSMR overlapped the WSMR colony-scale habitat model by $75.9 \%$ (Fig. 6). 
Fig. 6. White Sands Missile Range Pinyon Jay (Gymnorhinus cyanocephalus) colony-scale predictive habitat model. Inset shows nesting colonies. Colony model is shown in bright green; other land cover is shown in muted colors. Geospatial and vegetation data from within Colonies WA and WB were used to create the colony-scale model. Colony WC area was used for validation. Of the WC Colony area, $75.9 \%$ fell within the predictive model.
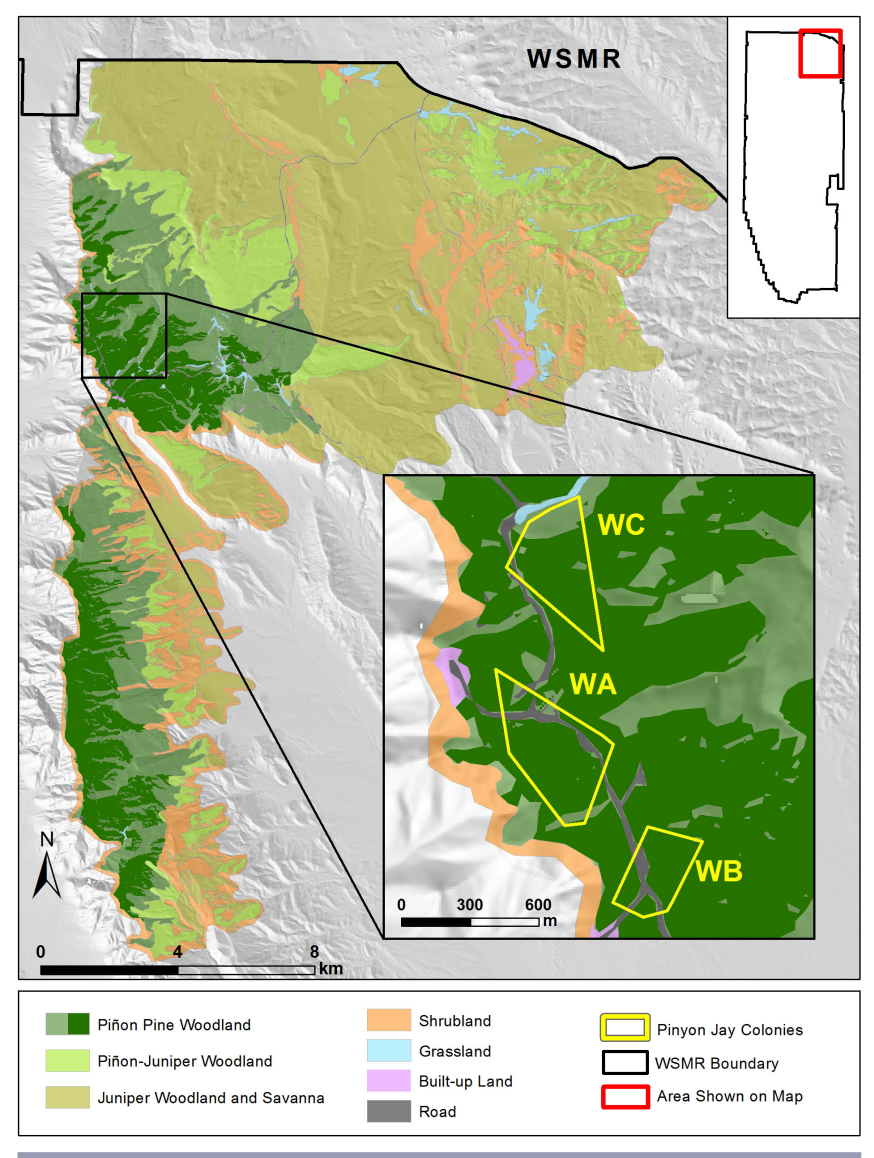

\section{DISCUSSION}

Balda (2002) noted that habitat use by Pinyon Jays had not been reported, and this has remained true until now. The lack of information on Pinyon Jay habitat use is surprising, given the long-term decline of this species (Sauer et al. 2014) and climate impacts to its habitat. Home range sizes, habitat types, differential habitat use within home ranges, and the approach to predictive colony-scale models presented here can provide a basis for conservation and management for Pinyon Jays in piñon-juniper habitats.

\section{Home range-scale models}

Pinyon Jay flock home ranges reported in the literature from various habitats vary widely: 1600 ha (Balda 2002), 2300 ha (Marzluff and Balda 1992), 2890 ha (Ligon 1971), and 6400 ha (Balda 2002). This variation among studies occurs in part because earlier estimates were not based on radio telemetry, and it is nearly impossible to closely follow a Pinyon Jay flock that is ranging widely. When satellite transmitters are developed that are small enough for a Pinyon Jay to safely carry, more accurate home range size estimates will be possible. However, even with better technology, home range sizes will likely vary because of differences in season, flock size, flock behavior, and habitat. For example, the KAFB breeding season home range is more than twice the area of the WSMR breeding season range, despite the smaller area of available piñon-juniper habitats at KAFB. This difference likely occurs because the KAFB flock nested at two widely-separated colony sites each year, compared to only one nesting colony site each year at WSMR. Balda (2002) presents a similar difference between home range sizes of two flocks.

For comparison, home range areas of breeding Clark's Nutcrackers, which are approximately $24 \%$ heavier than Pinyon Jays (Tomback 1998, Balda 2002), averaged only 200 ha, and those of nonbreeding individuals 400 ha (Schaming 2016). Like Pinyon Jays, Clark's Nutcrackers have a mutualism with a pine species, whitebark pine (P. albicaulis, Lanner 1996), but they are territorial breeders, much less social than Pinyon Jays, and eat a larger variety of pine seeds (Tomback 1998, Schaming 2016). The large sizes and various vegetation types characteristic of Pinyon Jay home ranges are probably a result of their mutualism with piñon trees, unpredictability of piñon mast crops, and perhaps sociality, although for sociality the causal relationship may be reversed. Other North American bird species that depend on mast also make large winter movements: Blue Jay (Cyanocitta cristata), Red-headed Woodpecker (Melanerpes erythrocephalus), and Black-capped Chickadee (Poecile atricapillus; Smith 1986).

Within their large home ranges, Pinyon Jays showed seasonal differences in habitat use, with lower-elevation Juniper Woodland and Savanna and Grassland (KAFB only) habitats used in winter and higher elevation habitat types with denser trees used for nesting. This pattern is more apparent at KAFB, where we have more nonbreeding-season occurrence data. Nonetheless, WSMR Pinyon Jays used high-elevation Piñon Woodland heavily in the early nonbreeding season, compared to KAFB jays. This result could be due to higher warm-season temperatures at WSMR at similar elevations. This example indicates that Pinyon Jay use of vegetation types within home ranges can be highly variable.

Radio telemetry enabled us to collect a substantial number of point locations over several months, but on several occasions, we were unable to locate some transmitters known to be functional. Our inability to find jays at these times could be due to the birds' mobility, their large home ranges, or the limitations of telemetry equipment in rough terrain. The home range for both study sites may therefore be an underestimate, particularly in winter when the species may wander widely (Marzluff and Balda 1992). Our home ranges may also under-represent the higher elevation vegetation types, because even with telemetry, it is difficult to cover the higher elevation habitats where roads are sparse or nonexistent. The home range polygons were based on occurrence data from years with no piñon mast crop. In the fall months of a mast year, Pinyon Jays would be expected to be harvesting seeds from large trees in piñon-dominated woodland. This would result in the inclusion of more Piñon Woodland in the nonbreeding home ranges. 


\section{Colony-scale models}

Habitat use analyses for birds typically involve creation of linear statistical models incorporating ground measurements at nests (Drever et al. 2015), geospatial data at larger scales such as forest patches (Girvetz and Greco 2009), or a combination of data from different scales (Lawler and Edwards 2006, Doherty et al. 2010, Drever et al. 2015, Jedlikowski et al. 2016). Although existing multiscale models often incorporate land cover data, most focus on nesting habitat only (not year-round home ranges), and even data considered landscape scale are at smaller scales than those required for Pinyon Jays (Girvetz and Greco 2009, Doherty et al. 2010, Jedlikowski et al. 2016).

Because Pinyon Jays nest colonially, the number of available colonies for statistical analysis is limited, and a single nesting colony covers tens of hectares, encompassing wide variation in geospatial measures. A nesting colony therefore cannot serve as a single data point for statistical modeling, as could a nest or territory. These attributes of nesting colonies constrained our ability to conduct analyses within a linear modeling framework, and a different approach to modeling at the colony scale was necessary. We used geospatial modeling techniques and land cover models to classify the study area, then identified sites having suites of topographic and vegetation features similar to those of existing colonies. The resulting geospatial models predict where Pinyon Jays are expected to establish colonies. The usefulness of this approach is indicated by the validation colonies, which fell within the predictive model at both study sites.

The polygons in the KAFB colony-scale model include a mix of Piñon-Juniper Woodland and Piñon Woodland habitat (Fig. 5), whereas the nesting colony model at WSMR contains only Piñon Woodland (Fig. 6). As at the home range scale, differences between the nesting colony models at the two sites and the topography and vegetation variation within KAFB colonies indicate that suitable Pinyon Jay nesting colony habitat includes a fairly large range of vegetation types and topographies, even though colony models cover only $10-15 \%$ of the available habitat.

Colony-scale models at both study sites were based on nesting data from March-July, but these models likely apply to other months in which Pinyon Jays have been reported nesting. When Pinyon Jays nest in colder months, incidence of solar radiation at the nest tree is influential, because it can reduce energetic costs to nesting females (Marzluff 1988). Given that habitat choice for nest temperature occurs at the tree, rather than the colony scale, colony-scale attributes are probably applicable to winter nesting, but this question requires further investigation.

\section{Scale considerations}

This study highlights the importance of scale in habitat modeling. Although the two study sites are separated by a little over $1^{\circ}$ of latitude ( $135 \mathrm{~km}$, Fig. 1), the elevation at these sites within Pinyon Jay habitat is similar, differing by less than $80 \mathrm{~m}$ at the lowest and $20 \mathrm{~m}$ at the highest elevations. A comparison of WSMR and KAFB colony-scale models suggests two useful conclusions. First, Pinyon Jay nesting colony habitat characteristics can vary broadly across large landscapes, as can within-site diversity of biophysical and vegetation features. Second, variation in topography and vegetation between and within study sites is only evident at the nesting colony scale.
What happens when a third, finer-scale model is considered? Nestscale models suggest that general rules for choosing nest sites may be similar between study sites, while habitat specifics differ. For example, Pinyon Jays at several colonies nested in larger-than average trees with denser cover over the nest, but the sizes and species of nest trees varied according to the available trees at each site (Johnson et al. 2014, 2015). The only other studies on choice of nest site were conducted in urban ponderosa pines (Gabaldon 1979, Marzluff 1988), but results have some similarities to our nest-scale habitat study. Gabaldon (1979) found that Pinyon Jays also nested in taller ponderosa pine trees with denser foliage over the nest.

\section{Conservation}

Extensive Pinyon Jay home ranges mean that only land managers with jurisdiction over very large piñon-juniper landscapes can effectively manage for the year-round habitat needs of even one Pinyon Jay flock. Home range- and larger scale conservation must include various piñon-juniper subtypes for variable use among seasons: lower-elevation Juniper Woodland and Savanna (and sometimes Grassland) in winter and higher-elevation PiñonJuniper and Piñon Woodlands for nesting and seed harvesting.

Even given recent piñon die-offs, suitable piñon-juniper nesting habitats currently appear to be abundant across the western USA. However, we found suitable nesting colony habitat in only about $10 \%$ and $15 \%$ of the study areas containing potential nesting habitat. As the quality of that nesting habitat declines with changing climate (K. Johnson, G. Sadoti, and J. Smith, unpublished manuscript), patches of suitable nesting habitat large enough to accommodate Pinyon Jay colonies are likely to become rare. If one model (McDowell et al. 2016) proves correct, most of the Pinyon Jay's nesting and foraging habitat in the southwestern USA will be lost by the year 2100 .

In addition to affecting availability of nesting habitat, climate change may be impacting the size and frequency of mast crops (Zlotin and Parmenter 2008, Redmond et al. 2012) important to Pinyon Jay population viability (Marzluff and Balda 1992). Cone production in piñon trees is quite spatially and temporally variable under the best of circumstances (Lanner 1981). If climate change is affecting mast crops, habitat conservation on a large landscape scale, to account for spatial and temporal variation and reduction in mast crops, would be crucial for Pinyon Jay conservation.

Conservation of large landscapes for Pinyon Jays may be effective but is probably not feasible, especially under the multiple-use policies of most land management agencies in the USA. Understanding of a species' habitat needs at smaller scales offers potential for conservation action at more limited and feasible spatial and temporal scales. For example, thinning for fuels reduction within nesting colonies may negatively impact the quality of Pinyon Jay nest habitat (Johnson et al. 2014). Avoiding thinning or development in predicted nesting colony sites (just $15.35 \%$ of the study area mapped at KAFB and $10.3 \%$ at WSMR) would protect all used and potential nesting habitat at those study areas. Restricting other human impacts such as recreation or military activities for just three to four months of the breeding season within the colony-scale model would provide significant support for nesting jays. Piñon-producing areas and nearby caching sites could be set aside for Pinyon Jays and other wildlife during the fall season in mast years only. 
Another climate-mediated cause of decline could be limited availability of free water (Gutzler 2013). Our colony-scale data reveal that Pinyon Jays used natural or artificial water sources near 10 nesting colonies we have studied. The jays established a nesting colony in atypical Juniper Woodland and Savanna habitat near our feeder, suggesting that Pinyon Jay nesting colony locations can be influenced by the presence of feeders. Marzluff and Balda (1992) also showed Pinyon Jays nesting near feeders in northern Arizona. Providing supplemental food and water near traditional nesting colony sites and elsewhere within flock home ranges is a simple, inexpensive, colony-scale management action that could ameliorate climate-related fluctuations in piñon seed and water availability and thereby increase Pinyon Jay climate resilience. Strategic placement of supplemental food and water could potentially assist managers to influence nesting colony location or movement. These colony-scale, spatially and temporally focused management actions would not be apparent from home range-scale models alone.

Responses to this article can be read online at: http://www.ace-eco.org/issues/responses.php/890

\section{Acknowledgments:}

This study was funded by grant \#09-425 from the Department of Defense Legacy Resource Management Program. We thank Kirtland Air Force Base and White Sands Missile Range for providing access to study sites and logistical support. Lisa Arnold created the solar radiation layer. Paul Neville helped create the $K A F B$ vegetation map. Matthew Baumann, Jason Kitting, Nathan Petersen, Eric Smith, and Cole Wolf collected Pinyon Jay observation data. Penny Frazier provided P. edulis seeds. Three reviewers provided helpful comments on earlier versions of the manuscript.

\section{LITERATURE CITED}

Allen-Reid, D., J. Anhold, D. Cluck, T. Eager, R. Mask, J. McMillin, S. Munson, J. Negron, T. Rogers, D. Ryerson, E. Smith, B. Steed, and R. Their. 2008. Piñon pine mortality event in the Southwest: an update for 2005. In G. R. Gottfried, J. D. Shaw, and P. L. Ford, compilers. 2008. Ecology, management, and restoration of piñon-juniper and ponderosa pine ecosystems: combined proceedings of the 2005 St. George, Utah and Albuquerque, New Mexico workshops. Proceedings RMRS-P-51. U.S. Department of Agriculture Rocky Mountain research station, Fort Collins, Colorado, USA. [online] URL:http://fhm. fs.fed.us/posters/posters05/pinon_pine.pdf

Bailey, F. M. 1928. Birds of New Mexico. New Mexico Department of Game and Fish, in cooperation with State Game Protective Association and U.S. Department of Agriculture Bureau of Biological Survey. Washington, D.C., USA.

Balda, R. P. 2002. Pinyon Jay (Gymnorhinus cyanocephalus). In A. Poole and F. Gill, editors. The birds of North America. No. 605. The Birds of North America Inc., Philadelphia, Pennsylvania, USA.
Berger, L. R., and J. D. Ligon. 1977. Vocal communication and individual recognition in the Piñon Jay, Gymnorhinus cyanocephalus. Animal Behaviour 25:567-584. http://dx.doi. org/10.1016/0003-3472(77)90107-5

Breshears, D. D., N. S. Cobb, P. M. Rich, K. P. Price, C. D. Allen, R. G. Balice, W. H. Romme, J. H. Kastens, M. L. Floyd, J. Belnap, J. J. Anderson, O. B. Myers, and C. W. Meyer. 2005. Regional vegetation die-off in response to global-change-type drought. Proceedings of the National Academy of Sciences 102:15144-15148. http://dx.doi.org/10.1073/pnas.0505734102

Chander, G., B. L. Markham, and D. L. Helder. 2009. Summary of current radiometric calibration coefficients for Landsat MSS, TM, ETM+, and EO-1 ALI sensors. Remote Sensing of Environment 113:893-903. http://dx.doi.org/10.1016/j.rse.2009.01.007

Clifford, M. J., N. S. Cobb, and M. Buenemann. 2011. Long-term tree cover dynamics in a pinyon-juniper woodland: climatechange-type drought resets successional clock. Ecosystems 14:949-962. http://dx.doi.org/10.1007/s10021-011-9458-2

Cole, K. L., K. Ironside, S. Arundel, P. Duffy, and J. Shaw. 2007. Modeling future plant distributions on the Colorado Plateau: an example using Pinus edulis. Pages 319-330 in C. van Riper III and M. Sogge, editors. The Colorado Plateau III: integrating research and resources management for effective conservation. University of Arizona Press, Tucson, Arizona, USA.

Dick-Peddie, W. A. 1993. Ecology and diversity of pinyon-juniper woodland in New Mexico. In E. F. Aldon and D.W. Shaw, technical coordinators. Managing pinyon-juniper ecosystems for sustainability and social needs; proceedings of the symposium 1993 April 26-30, Santa Fe, New Mexico. General Technical Report RM-236. U.S. Forest Service, Rocky Mountain Forest and Range Experiment Station, Fort Collins, Colorado, USA.

Doherty, K. E., D. E. Naugle, and B. L. Walker. 2010. Greater Sage-Grouse nesting habitat: the importance of managing at multiple scales. Journal of Wildlife Management 74:1544-1553. http://dx.doi.org/10.2193/2009-043

Drever, M. C., L. W. Gyug, J. Nielsen, A. K. Stuart-Smith, I. P. Ohanjanian, and K. Martin. 2015. Using field data and GISderived variables to model occurrence of Williamson's Sapsucker nesting habitat at multiple scales. PLoS ONE 10(7):e0130849. http://dx.doi.org/10.1371/journal.pone.0130849

ERDAS. 2011. ERDAS IMAGINE: Release 10. ERDAS, Inc., Norcross, Georgia, USA.

Esri 2009. ArcGIS Desktop: Release 9. Environmental Systems Research Institute, Redlands, California, USA.

Esri 2011, ArcGIS Desktop: Release 10. Environmental Systems Research Institute, Redlands, California, USA.

Esri 2013. ArcGIS Desktop: Release 10.2. Environmental Systems Research Institute, Redlands, California, USA.

Ferrari, I., and A. Ferrarini. 2008. From ecosystem ecology to landscape ecology: a progression calling for a well-founded research and appropriate disillusions. Landscape Online 6:1-12. http://dx.doi.org/10.3097/LO.200806 
Gabaldon, D. J. 1979. Factors involved in nest site selection by Piñon Jays. Dissertation, Northern Arizona University, Flagstaff, Arizona, USA.

Girvetz, E. H., and S. E. Greco. 2009. Multi-scale predictive habitat suitability modeling based on hierarchically delineated patches: an example for Yellow-Billed Cuckoos nesting in riparian forests, California, USA. Landscape Ecology 24:1315-1329. http:// dx.doi.org/10.1007/s10980-009-9384-2

Gutzler, D. S. 2013. Regional climate considerations for borderlands sustainability. Ecosphere 4:1-12. http://dx.doi. org/10.1890/ES12-00283.1

Jedlikowski, J., P. Chibowski, T. Karasek, and M. Brambilla. 2016. Multi-scale habitat selection in highly territorial bird species: exploring the contribution of nest, territory and landscape levels to site choice in breeding rallids (Aves: Rallidae). Acta Oecologica 73:10-20. http://dx.doi.org/10.1016/j.actao.2016.02.003

Johnson, K., and J. Smith. 2006. Interdependence of pinyon pines and Pinyon Jays, White Sands Missile Range, NM: 2004-2005 final report. Natural Heritage New Mexico report, University of New Mexico Biology Department, Albuquerque, New Mexico, USA. [online] URL: http://nhnm.unm.edu/sites/default/files/nonsensitive/ publications/nhnm/U06JOH02NMUS.pdf

Johnson, K., and J. Smith. 2008. Pinyon Jays and pinyon pines at North Oscura Peak, White Sands Missile Range, New Mexico: 2007 annual report. Natural Heritage New Mexico Report 08GTR-328, University of New Mexico Biology Department, Albuquerque, New Mexico, USA. [online] URL: http://nhnm. unm.edu/sites/default/files/nonsensitive/publications/nhnm/ U08JOH01NMUS.pdf

Johnson, K., L. Wickersham, J. Smith, N. Petersen, and J. Wickersham. 2015. Nest-scale habitat use by Pinyon Jay and Gray Vireo in the BLM Farmington Resource Area 2013-2014, final report. Natural Heritage New Mexico Report GTR-15-386. University of New Mexico Biology Department, Albuquerque, New Mexico, USA. [online] URL: http://nhnm.unm.edu/sites/ default/files/nonsensitive/publications//FINAL $\% 202014 \% 20$ BLM $\%$ 20P-J $\% 20 \% 20$ report.pdf

Johnson, K., L. Wickersham, J. Smith, G. Sadoti, T. Neville, J. Wickersham, and C. Finley. 2014. Habitat use at multiple scales by pinyon-juniper birds on Department of Defense lands III: landscape, territory/colony, and nest scale. Natural Heritage New Mexico Report 14-GTR-381, University of New Mexico Biology Department, Albuquerque, New Mexico, USA. [online] URL: http://nhnm.unm.edu/sites/default/files/nonsensitive/publications// Year $\% 203 \% 20$ Legacy $\% 20$ FINAL2.pdf

Kirtland Air Force Base. 2007. Integrated natural resources management plan for Kirtland Air Force Base. Kirtland Air Force Base, Albuquerque, New Mexico, USA.

Lanner, R. M. 1981.The piñon pine: a natural and cultural history. University of Nevada Press, Reno, Nevada, USA.

Lanner, R. M. 1996. Made for each other: a symbiosis of birds and pines. Oxford University Press, New York, New York, USA.

Lawler, J. J., and T. C. Edwards Jr. 2006. A variancedecomposition approach to investigating multiscale habitat associations. Condor 108:47-58. http://dx.doi.org/10.1650/0010-5422 (2006)108[0047:AVATIM]2.0.CO;2

Ligon, J. D. 1971. Late summer-autumnal breeding of the Piñon Jay in New Mexico. Condor 73:147-153. http://dx.doi. org/10.2307/1365835

Ligon, J. D. 1978. Reproductive interdependence of Pinon Jays and pinon pines. Ecological Monographs 48:111-126. http://dx. doi.org/10.2307/2937295

Linsdale, J. M. 1936. The birds of Nevada. Pacific Coast Avifauna 23:1-145.

Marzluff, J. M. 1988. Do Pinyon Jays alter nest placement based on prior experience? Animal Behaviour 36:1-10. http://dx.doi. org/10.1016/S0003-3472(88)80244-6

Marzluff, J. M., and R. P. Balda. 1992. The Pinyon Jay: the behavioral ecology of a colonial and cooperative corvid. T \& AD Poyser, London, UK.

McDowell, N. G., A. P. Williams, C. Xu, W. T. Pockman, L. T. Dickman, S. Sevanto, R. Pangle, J. Limousin, J. Plaut, D. S. Mackay, J. Ogee, J. C. Domec, C. D. Allen, R. A. Fisher, X. Jiang, J. D. Muss, D. D. Breshears, S. A. Rauscher, and C. Koven. 2016. Multi-scale predictions of massive conifer mortality due to chronic temperature rise. Nature Climate Change 6:295-300. http://dx.doi.org/10.1038/nclimate2873

Middle Rio Grande Council of Governments (MRGCOC). 2008. Digital orthophotography. MRGCOC, Albuquerque, New Mexico, USA. [online] URL: http://rgis.unm.edu/getdata/

National Agriculture Imagery Program (NAIP). 2009. USDAFSA natural color digital aerial imagery acquired for New Mexico. NAIP, U.S. Department of Agriculture Farm Service Agency, Aerial Photography Field Office, Salt Lake City, Utah, USA.

National Solar Radiation Database. 2007. 1991-2005 Update: user's manual. Technical Report NREL/TP-581-41364. National Renewable Energy Laboratory, Golden, Colorado, USA.

Neatherlin, E. A., and J. M. Marzluff. 2004. Responses of American Crow populations to campgrounds in remote native forest landscapes. Journal of Wildlife Management 68:708-718. http://dx.doi.org/10.2193/0022-541X(2004)068[0708:ROACPT]2.0. $\mathrm{CO} ; 2$

Redmond, M. D., F. Forcella, and N. N. Barger. 2012. Declines in pinyon pine cone production associated with regional warming. Ecosphere 3:1-14. http://dx.doi.org/10.1890/ES12-00306.1

Romme, W. H., C. D. Allen, J. D. Bailey, W. L. Baker, B. T. Bestelmeyer, P. M. Brown, K. S. Eisenhart, M. L. Floyd, D. W. Huffman, B. F. Jacobs, R. F. Miller, E. H. Muldavin, T. W. Swetnam, R. J. Tausch, and P. J. Weisberg. 2009. Historical and modern disturbance regimes, stand structures, and landscape dynamics in piñon-juniper vegetation of the western United States. Rangeland Ecology and Management 62:203-222. http:// dx.doi.org/10.2111/08-188R1.1

Sauer, J. R., J. E. Hines, J. E. Fallon, K. L. Pardieck, D. J. Ziolkowski Jr., and W. A. Link. 2014. The North American breeding bird survey, results and analysis 1966 - 2013. Version 01.30.2015, USGS Patuxent Wildlife Research Center, Laurel, Maryland, USA. 
Schaming, T. D. 2016. Clark's Nutcracker breeding season space use and foraging behavior. PLOS ONE 11:e0149116. http://dx. doi.org/10.1371/journal.pone.0149116

Smith, K. G. 1986. Winter population dynamics of three species of mast-eating birds in the eastern United States. Wilson Bulletin 98:407-418.

Swain, P. H., and S. M. Davis. 1978. Remote sensing: the quantitative approach. McGraw Hill Book Company, New York, New York, USA.

Thompson, R. S., S. E. Hostetler, P. J. Bartlein, and K. H. Anderson. 1998. A strategy for assessing potential future changes in climate, hydrology, and vegetation in the western United States. U.S. Geological Survey Circular 1153. [online] URL: http://pubs. usgs.gov/circ/1998/c1153/

Tomback, D. F. 1998. Clark's Nutcracker (Nucifraga columbiana). In A. Poole and F. Gill, editors. The birds of North America online. No. 331. Cornell Lab of Ornithology, Ithaca, New York, USA. [online] URL: http://bna.birds.cornell.edu/bna/species/331/articles/ introduction

Western Regional Climate Center. 2010. Albuquerque WSFO Airport, New Mexico. Period of record monthly climate summary. Western Regional Climate Center, Reno, Nevada, USA. [online] URL: http://www.wrcc.dri.edu/cgi-bin/cliMAIN.pl?nmalbu

Zlotin, R. I., and R. R. Parmenter. 2008. Patterns of mast production in pinyon and juniper woodlands along a precipitation gradient in central New Mexico (Sevilleta National Wildlife Refuge). Journal of Arid Environments 72:1562-1572. http://dx. doi.org/10.1016/j.jaridenv.2008.02.021 
Appendix 1. Geospatial and remote sensing methods.

Using Esri ArcGIS ToolBox (Esri 2011), we derived our topographic predictors from a composite of 10-m digital elevation models (DEMs) for each of the sites. Each 10-m cell represents elevation above sea level in meters. From the DEMs we processed various derivatives including aspect, degree slope, and curvature. Aspect is calculated in a $3 \times 3$ window for each cell using its neighbors to identify the maximum rate of change in the downslope direction, then converted to compass direction. Resulting values ranged from 0 to 360 and were converted to an index of the aspect using the cosine of aspect. Values closer to 1 were northerly and those nearer -1 were southerly. Degree slope is a measure of the steepness of a slope from 0 to 90 degrees calculated as the maximum change in elevation from each cell using a $3 \times 3$ window. Curvature is essentially the slope intended to model topographic features; e.g., bowl-shaped features within foothills. This variable was included in an attempt to capture the topographic variety in the set of colonies where we studied Pinyon Jays.

Solar radiation determines micro-environmental factors on the Earth's surface. Because Pinyon Jays typically nest when temperatures can be quite cold, solar radiation may be an important factor in determining nest sites (Marzluff 1988, Marzluff and Balda 1992). We used the ArcGIS Solar Radiation tool set (Esri 2011) to create solar radiation surface models from 1 March - 15 April, when Pinyon Jays typically choose colony sites. For validation, we used a gridded data set of ground-based solar radiation values compiled by the State University of New York Albany (SUNY), available as part of the National Solar Radiation Database (2007). To generate a solar radiation surface over the extent of our study areas, we compared point solar radiation values calculated for our study areas by the tool to solar radiation values measured at a SUNY collection site central to each study area. The solar radiation model accounts for site latitude and elevation, surface orientation, shadows cast by surrounding topography, daily and seasonal shifts in solar angle, and atmospheric attenuation. To make the model representative of the designated time period, we parameterized the components of atmospheric attenuation (transmissivity and diffuse proportion) by testing different combinations and comparing our modeled point results to the measured solar radiation value based on the SUNY ground-based data. The best combination of transmissivity and diffuse proportion values resulted in only a $2 \%$ difference from the measured SUNY data. We then used the validated atmospheric variables and our 10-m DEM to create a continuous solar radiation surface for both study sites.

Pinyon Jays nest in larger trees with relatively higher canopy cover above and around the nest. Further, at the colony scale, jays abandoned colony sites with lower tree vigor, a measure of foliage thickness/greenness, and moved to areas with higher vigor (Johnson et al. 2014). To capture foliage greenness, we created Normalized Difference Vegetation Indices (NDVIs) for the study areas from Landsat 5 data acquired in 2005. January, July, and October scenes were acquired to maximize information on seasonal changes and differentiate structural and compositional elements in vegetation cover.

Prior to developing the indices, we exoatmospherically and radiometrically corrected the Landsat multispectral reflective bands 1-5 and 7, following Chander et al. (2009). These correction 
procedures account for inconsistencies due to changes in sensor calibration and differences in illumination. The index (Eqn. 1.1) emphasizes relative plant vigor by taking advantage of the near infrared (NIR) reflected response of green leaf concentration against the visible red radiation (Red) response which is absorbed by green vegetation:

Eqn. 1.1: NDVI= (NIR - Red $) /(\mathrm{NIR}+\mathrm{Red})$

Radiometric calibration (Eqn. 1.2) converts the 8-bit digital numbers $\left(\mathrm{Q}_{\text {cal }}\right)$ representing brightness values between 0 and 255 to radiance values $(\mathrm{L} \mu)$, while accounting for the variations in gains $\left(\mathrm{G}_{\text {rescale }}\right)$ and biases $\left(\mathrm{B}_{\text {rescale }}\right)$ of individual sensors due to sensor degradation:

$$
\text { Eqn. 1.2: } \mathrm{L} \mu=\left(\mathrm{Q}_{\text {cal }} \cdot \mathrm{G}_{\text {rescale }}\right)-\mathrm{B}_{\text {rescale }}
$$

The exoatmospheric correction (Eqn. 1.3) applied to the individual pixels for each band accounts for the seasonal differences of the Earth-Sun distance $(d)$, solar elevation angle $(\Theta)$, and bandwidth variations in solar irradiance $(\mathrm{ESUN} \mu)$. Outputs from the model are surface reflectance values $(\rho)$ :

$$
\text { Eqn. 1.3: } \rho=\mathrm{L} \mu \cdot \pi \cdot \mathrm{d}^{2} / \mathrm{ESUN} \mu \cdot \cos \Theta
$$

We developed a "deciduous greenness" index by subtracting the January NDVI, when vegetation was senescent, from the October NDVI (approximating maximum "green-up") to determine if other vegetation such as grasses and shrubs within the juniper savanna and woodland were important in colony site selection. We resampled the Landsat data from $30 \mathrm{~m}$ to $10 \mathrm{~m}$ to match the other digital datasets.

With ERDAS Imagine Spatial Modeler (ERDAS 2011), we created vegetation indices. The normalized difference senescent vegetation index (NDSVI, Eqn.1. 4) enhances the spectral characteristics of senescent vegetation, specifically grasses, which have a relatively low reflectance response in the red wavelengths (Red, Band 3) and a high reflectance in the midinfrared wavelengths (MIR7, Band 7). The moisture index (Eqn. 1.5) compares relatively high reflectance values in the shorter wavelengths of the mid-infrared (MIR5, Band 5) against strong absorption at the longer wavelengths of the mid-infrared (MIR7, Band 7) caused by water molecules found in soil and vegetation.

Eqn. 1.4: NDSVI $=($ MIR7 - Red $) /($ MIR7 + Red $)$

Eqn. 1.5: Moisture Index $=($ MIR5 - MIR7) $/($ MIR5 + MIR7)

We compiled all layers into a single image and re-sampled to $10-\mathrm{m}$ spatial resolution. The image file contained 15 layers available for the classification process. 


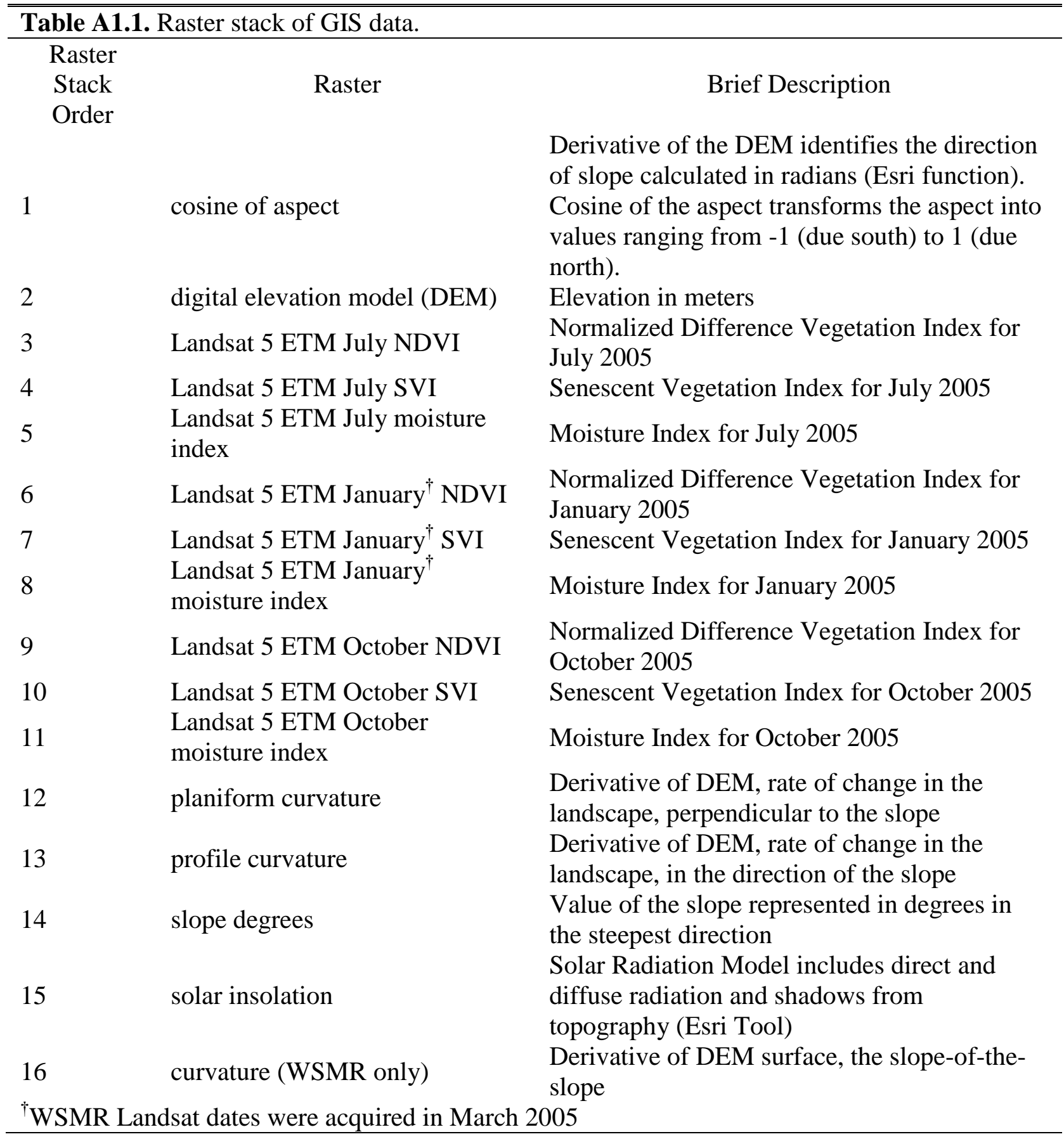

